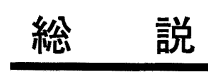

\title{
ジペプチド結晶場による分子認識
}

\author{
小 倉 克 之 \\ 千葉大学工学部応用化学科 \\ （干263 千葉市稲毛区弥生町 1-33）
}

\section{Molecular Recognition by Crystalline Dipeptides}

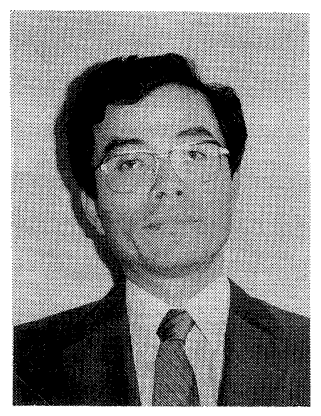

\author{
Katsuyuki OGURA \\ Chiba University, Faculty of Engineering, Department of Applied Chemistry \\ (1-33 Yayoicho, Inage-ku, Chiba-shi, =263)
}

A distinct feature of a dipeptide is a straight structure bearing an amino group at one terminal and a carboxyl group at another terminal because a hardly rotatable peptide linkage exits at its center. As a result, dipeptide molecules are arranged in atwo-dimensional layer.

On stirring crystalline $(R)$-phenylglycyl- $(R)$-phenylglycine (1) and isopropyl phenyl sulfoxide ( 2 a) in the presence of water, $(S)-2$ a molecules widened the channel between the peptide layers to be accomodated under asymmetric recognition. The driving forces of this accomodation is hydrogen bonding between $\mathrm{H}_{3} \mathrm{~N}^{+}$group and sulfinyl group, phenyl-phenyl edge-to-face interaction, and $\mathrm{CH}-\pi$ interaction of the isopropyl of 2 a with the phenyl of 1 . $(R)$-Methyl phenyl sulfoxide was stereo-selectively intercalated into crystalline 1 . These phenomena were also observed by the peptide (1)-deposited quartz-crystal microbalance.

In contrast with 1, $(R)$-(1-naphthyl) glycyl-( $R$ )-phenylglycine (5) always requires an appropriate guest molecule to maintain a crystalline structure because relatively large naphthyl group disturbs contraction of the peptide layers. Indeed, the dipeptide (5) forms the crystals including a guest molecules (an alcohol, an ether, or sulfoxide) on crystallization from methanol containing the guest. It is noteworthy that the guest exchange is possible by simply stirring the inclusion crystals with other guest molecules in carbon tetrachloride. The layer arrangement in these inclusion crystals was revealed by single-crystal X-ray analysis.

\section{1 はじめに}

“有機分子が有機分子を認識する”ことは, 生体内の 様々な受容体による基質の認識に代表される。これらの 認識には水素結合や蹯水性相互作用という弱い分子間力 が重要であり, 様々な方面から研究が行われてきた。も ちろん，多くの有機反応や触媒反応でも分子間相互作用 がその立体選択性や反応速度に重大な影響を及ぼすこと は，周知のとおりである。疎水性相互作用として片づけ られているものを詳細に眺めると，(1)芳香環がパラレル に並んで作用をする $\pi-\pi$ スタッキング相互作用 ${ }^{1)}$, (2)ベ ンゼン環とベンゼン環が直交して働く edge-to-face 型 相互作用 ${ }^{2)}$, (3)ベンゼン環とアルキル基の水素との間に 働く $\mathrm{CH}-\pi$ 相互作用 ${ }^{3)}$, (4)アルキル基同士の間に働く London 分散力, を挙げることができる。
有機分子と有機分子との相互作用に関する研究の多く は, 有機分子を認識できる空孔 (分子認識場) の構築と その分子認識能の検討に始まる。分子認識場の設計とし て, まずシクロデキストリン, クラウンエーテル類, ク リプタンド, シクロファン, カリックスアレーンといっ たホスト分子を挙げることができる。これらは，ゲスト 分子を認識できるほぼ大きさの決まった空孔をあらかじ め備えており，いわゆる「かぎ(鍵)と鍵穴」モデルであ る。

一方, 分子が一定のパターンに基づいて集合体を形成 すると，個々の分子では見られない新しい機能が生まれ $3^{4)}$ 。分子の組織化であり, 水素結合を利用した尿酸5) やデオキシコール酸誘導体 ${ }^{6}$ ) 結晶場にその例を見ること ができる。分子集合体による分子認識では, ゲスト分子 に応じて柔軟にその組織を変化させ, ゲストに見合う空 


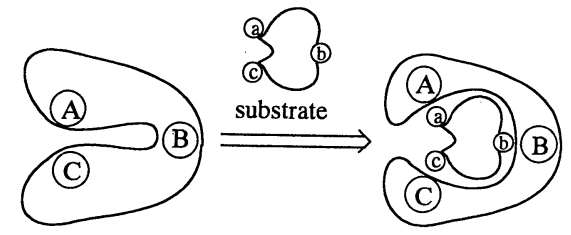

Fig.-1 "Flexible" model for receptors.

孔を用意することが多く，「柔軟な分子認識場」モデル (Fig.ー1) となる。

分子集合体を形成するための駆動力として，前述の水 素結合のほか, 金属への配位結合や塩形成などが考えら れる。たとえば, $\mathrm{L}_{2} \mathrm{Pd}\left(\mathrm{NO}_{3}\right)_{2}(\mathrm{~L}=1,2$-diaminoethane) と 2 個の 4-ピリジル基を有する配位子との反 応では, 分子認識能を有する大環状二核あるいは四核錯 体が自己組織化する ${ }^{7)}$ 。また, アミノ酸やペプチドは両 性化合物であり, 塩形成による分子集合体を与えること ができる。そこで, 我々はジペプチドの特異な性質に着 目し，その分子集合体による分子認識空孔（ホスト）の 形成と基質（ゲスト）との分子間相互作用についても研 究を行ってきた。ジペプチド分子は, 分子中央のアミド 部位は平面性が大きく, 剛直な直線分子と見なすことが できる。また，末端 $\mathrm{COO}^{-}$と他分子の末端 ${ }^{+} \mathrm{NH}_{3}$ との イオン結合 (塩形成) で配列でき, 分子集合体を構築で きる。

\section{$2(\boldsymbol{R})$-フェニルグリシルー $(\boldsymbol{R})-$ フェニル グリシン結晶場の分子認識}

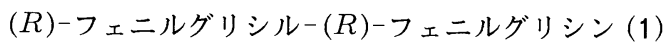
は, 水にも有機溶媒にも溶けないジペプチドで, たいへ ん密にパックされた固体 (結晶) である。

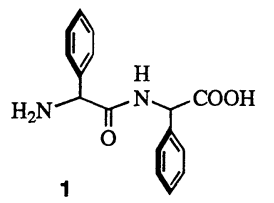

1 を水に懸濁し，アルキルフェニルスルホキシド (2) 共存下室温でかくはんすると, スルホキシドが不斉認識

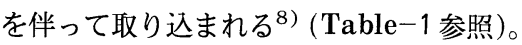

$(S)$-イソプロピルフェニルスルホキシド (2 a ) を不斉 認識して取り込んだ包接結晶では, 単結晶が得られ, そ の構造を X 線解析で明らかにできた。ジペプチドは層 を形成し，その層間（チャンネル）に2 a を取り込んで いる(Fig. -2)。

ジペプチド層のみを横 ( $\mathrm{b}$ 軸) から見ると, Fig.-3の ようになる。層形成には，ジペプチド分子間の $\mathrm{COO}^{-}$ 基と ${ }^{+} \mathrm{NH} 3$ 基との塩形成はもちろん, 塩形成によって
Table-1 Inclusion of sulfoxides by crystals of $1 .^{\mathrm{a}}$

\begin{tabular}{|c|c|c|c|}
\hline \multirow{2}{*}{ Sulfoxide (2) } & & \multicolumn{2}{|c|}{ The sulfoxide included in 1} \\
\hline & & Yield/\% & $e e / \%$ \\
\hline $\mathrm{SOCH}\left(\mathrm{CH}_{3}\right)_{2}$ & (2a) & 73 & $81(S)$ \\
\hline$-\mathrm{SOC}\left(\mathrm{CH}_{3}\right)_{3}$ & (2 b) & 83 & $60(S)$ \\
\hline $\mathrm{SOCH}_{2} \mathrm{CH}_{2} \mathrm{CH}_{3}$ & $(2 \mathrm{c})$ & 0 & - \\
\hline $\mathrm{SOCH}_{2} \mathrm{CH}_{3}$ & (2d) & 0 & - \\
\hline $\mathrm{SOCH}_{3}$ & $(2 \mathrm{e})$ & 35 & $92(R)$ \\
\hline
\end{tabular}

a A sulfoxide (ca. $2 \mathrm{mmol}$ ) was stirred with 1 (1 $\mathrm{mmol})$ in the presence of water $(2 \mathrm{~mL})$ at room temperature.

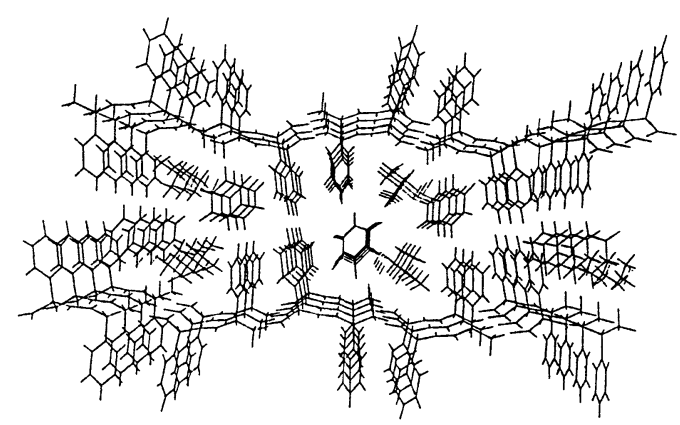

Fig.-2 Perspective view down the stacking axis (z) for the inclusion complex of dipeptide (1) and (S)-2 a. (a)

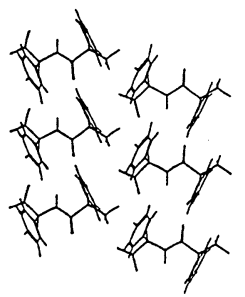

(b)

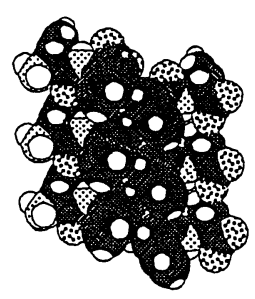

Fig.-3 Side view for the layers of dipeptide (1). (a) the front (wire model). (b) the back (space-filling model).

隣接したフェニル基間の edge-to-face 型 $\mathrm{CH}-\pi$ 相互作 用も重要である。このように, ジペプチド (1) は, 層を 形成するのに極めて都合の良い構造をしたジペプチドで あると言える。

さらに，スルホキシドを取り込んだ包接結晶ををジク ロロメタンで洗浄すると, スルホキシドを取り出せる。 


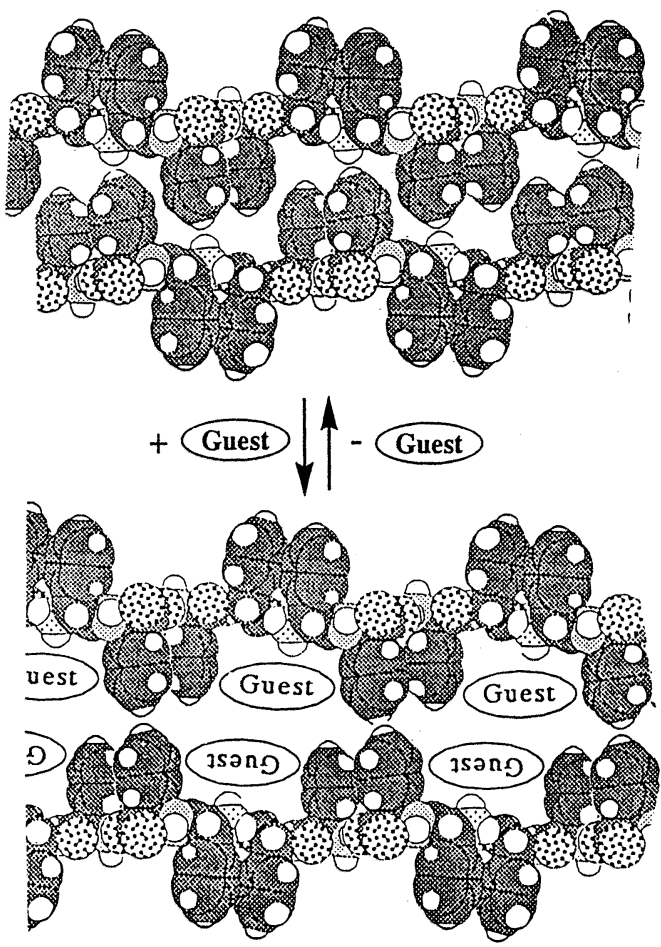

Fig. -4 Change of layer distance during the insertion of $(S)-2$ a into crystalline dipeptide (1).

残ったジペプチドの粉末 $\mathrm{X}$ 線回折パターンは, スルホ キシドを取り込む前のものと一致した。このパターンに は, $7.0 \AA と 7.8 \AA$ の層間隔に相当するピークがみら れ，スルホキシドを取り込んだ結晶の層間隔 $(13.0 \AA)$ は消失した。このようなことから，1の結晶場は，その 層間隔を広げ，スルホキシドを取り込み，有機溶媒によ る洗浄でスルホキシドを放出し，層間をもとに縮めるこ とが分かった (Fig.-4)。

スルホキシドを取り込む駆動力は, Fig.-5に示すよ うに, ジペプチドの ${ }^{+} \mathrm{NH}_{3}$ 基とスルホキシド酸素の水 素結合， ジペプチドのフェニル基とスルホキシドのフェ ニル基との間の edge-to-face 型 $\mathrm{CH}-\pi$ 相互作用，およ びスルホキシドのイソプロピル基とフェニル基の $\mathrm{CH}-\pi$ 相互作用である。

メチルフェニルスルホキシド (2 e ) も同様に 1 の結晶 場に取り込まれるが, 優先的に取り込まれる立体配置は $R$ である (Table-1)。エチルフェニルスルホキシド $(2$ c) は, 単に水共存下でかくはんするだけでは 1 の固相 に取り込まれない。しかし，水の代わりにへキサンを共 存させてかくはんすると, 1 の固相中に取り込まれる。 水共存下では水素結合による駆動力が固相内外で相殺さ れるためであり，エチル基とジペプチドフェニル基との

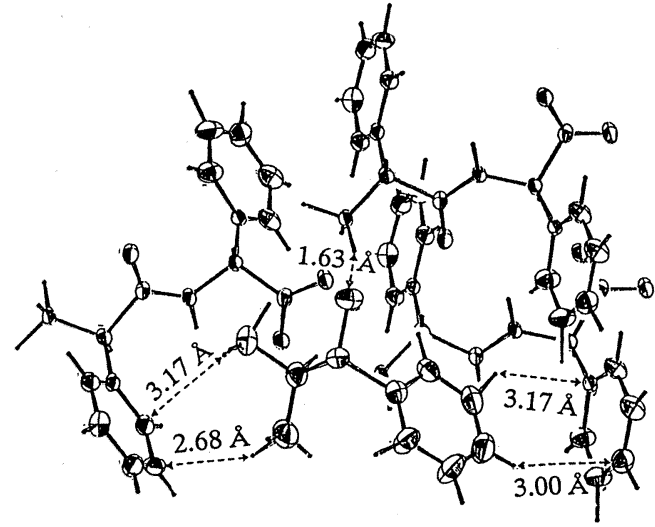

Fig. -5 ORTEP view for one molecule of $(S)-2$ a and three molecules of dipeptide (1) which contact with the $(S)-2$ a.

Table-2 Inclusion of sulfoxide (3) by crystals of $1 .^{\text {a }}$

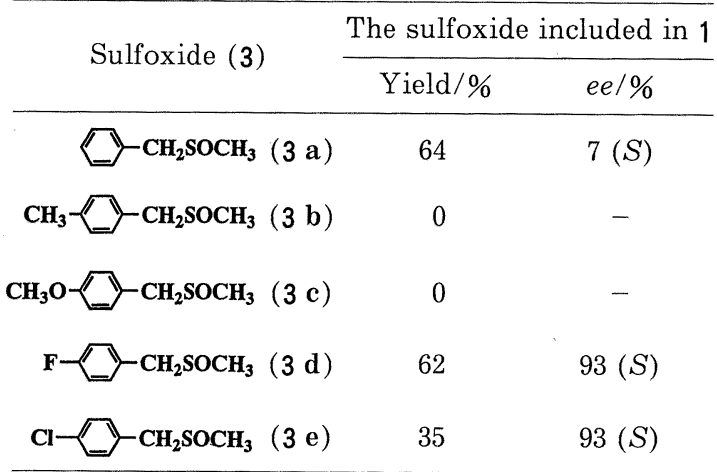

a A sulfoxide (ca. $2 \mathrm{mmol}$ ) was stirred with 1 (1 $\mathrm{mmol})$ in the presence of water $(2 \mathrm{~mL})$ at room temperature.

$\mathrm{CH}-\pi$ 相互作用がイソプロピル基に比べて, 弱いと解 釈できる。医薬（たとえば，プロプラノロール9)のよう な $\beta$-ブロッカー）や農薬（たとえば，フェンバレレイ ト10)のようなピレスロイド) で，イソプロピル基を有 する化合物が多い事実と一致した現象である。

ベンジルメチルスルホキシドおよびその $p$-置換体(3) で, 興味ある挙動が見られる11)。1の結晶場による取 り込みの結果を Table-2にまとめたが, ベンジルメチ ルスルホキシドそのものに取り込まれるものは, ほぼラ セミ体である。 $p$-置換基が電子求引性基になると, 不 斉認識率が高くなる。アルキルフェニルスルホキシド （2）のフェニル基では電子求引性スルフィニル基が直結 していたが，3ではそれがない。 $p$ 位電子求引性置換基 によって, ジペプチドのフェニル基と 3 のフェニル基と の間の edge-to-face型 $\mathrm{CH}-\pi$ 相互作用が大きくなり, 不斉認識率が高くなったと考えることができる。 
3 水晶発振子にキャストした $(R)$-フェニルグ リシルー $(R)$-フェニルグリシンジ層による 分子認識

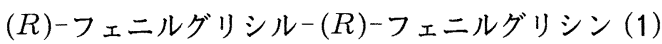
微結晶をクロロホルムに分散させたのち，この懸濁液を 水晶発振子上にキャストして, 固定化できる ${ }^{12)}$ 。水中 で様々なゲスト化合物を添加すると，ゲスト分子がキャ ストした 1 の層に吸着する様子が発振子の振動数の減少 （キャスト層の重量増加）で観測できる。たとえば，メ チルフェニルスルホキシドの添加では $R$ 体の方が $S$ 体 よりも振動数が大きく減少し, 吸着量が多いことが示さ れた。

イソプロピルフェニルスルホキシドは他のアルキル フェニルスルホキシドに比べて多量に吸着する。飽和吸 着量はジペプチド分子とほぼ等モル量となり, 前項の取 り込み実験之同一の結果となった。この発振子に固定化 したジペプチドは, ジペプチド単独の結晶場とは異なっ た挙動もする。アルコール類の吸脱着も観測された。 1-ノナノールと2-ノナノールが, 5-ノナノールに比べ てよく吸着される。1-フェニルエタノールでの吸着で は，不斉認識はほとんど観測されない。

ジペプチド固定化発振子を L-ロイシン誘導体 (4a) 水溶液に入れ, 液温を徐々に上昇させた。温度の上昇と ともに，振動数が減少（吸着量が増加）し， 4 a がジペ プチド層に取り込まれていることが分かった。粉末 X線 回折測定から, 層間隔は $12 \AA$ に広がっていることが確

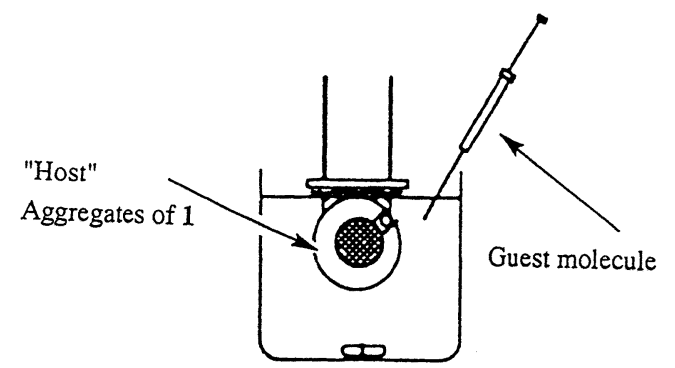

Fig.-6 Schematic illustration for molecular recognition process of dipeptide (1)-deposited quartz-crystal microbalance.
認されたが, 室温に下げても $4 \mathrm{a}$ は放出されない。アラ ニンやバリン誘導体 $(4 \mathrm{~b}$ と $4 \mathrm{c}$ ) でも同様の立体特異的 な認識が見られたが，フェニルアラニンやグリシン誘導 体は取り込まれなかった ${ }^{13)}$ 。

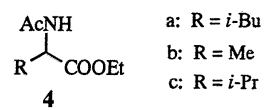

L-ロイシン誘導体 (4a) を取り込んだキャストジペ プチドをメタノールで洗浄すると, $4 \mathrm{a}$ を除去できる。 しかし, ジペプチドの層間隔は減少せず, 発振子にキャ ストしたことによる特異性と解釈される。 $4 \mathrm{a}$ を脱着し たジペプチド固定化発振子を再び水中に浸し， $4 \mathrm{a}$ の L 一体と D-体をそれぞれ別々に加えると，両者とも吸着 した。しかし, 吸着飽和後, 水を新しくすると, $\mathrm{D}$ 一体 のみが脱着し，L-体はほとんど脱着しなかった。した がって, L-体でインプリントしたジペプチド結晶の層 間は L-体を強く吸着することが分かった。

\section{$4(\boldsymbol{R})-(1$-ナフチル) グリシル- $(\boldsymbol{R})-$ フェニル グリシン結晶場による分子認識}

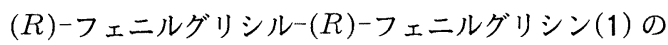
フェニル基を1-ナフチル基に代えると, ナフチル基同 志の立体反発によって層間隔を縮小することはできず,

層（結晶）構造を保つには常に何らかのゲスト分子の存 在が必要になる。

ジペプチド (1) の層形成には塩形成によって隣接した フェニル基間の edge-to-face $\mathrm{CH}-\pi$ 相互作用も重要で あったが，ナフチル基に置換することにより，この相互 作用が弱まり, より柔軟に層構造になることも期待され る。

$(R)-(1-$ ナフチル) グリシル- $(R)-$ ェニルグリシン (5) をメタノールから再結晶すると, メタノールを包接 して結晶化する。このような現象は 1 では全く観測され ない。先に予想したように, 層間にメタノール分子を包 接して結晶構造が維持されたためであろう。粉末 $\mathrm{X}$ 線回 折の結果, 層間隔は $11.3 \AA$ であった ${ }^{14) 。 ~}$

5 のメタノール溶液に他のアルコールを加えて放置す ると, 包接結晶が析出した。 ${ }^{1} \mathrm{H}-\mathrm{NMR}$ と元素分析の結

Table-3 Kinetic parameters of binding $\left(k_{1}\right)$ and dissociation $\left(k_{-1}\right)$ of 4 a into the 1 aggregates on quartz-crystal microbalance at $25^{\circ} \mathrm{C}$.

\begin{tabular}{ccccc}
\hline Host & Guest & $k_{1} / \mathrm{dm}^{3} \cdot \mathrm{mol}^{-1} \cdot \mathrm{s}^{-1}$ & $k^{-1} / 10^{-3} \mathrm{~s}^{-1}$ & $K_{a} / \mathrm{dm}^{3} \cdot \mathrm{mol}^{-1}$ \\
\hline Non-imprinted 1 & L-4 a & 8.7 & 2.6 & 340 \\
& D-4 a & 7.2 & 2.2 & 330 \\
1 imprinted with 4 a & L-4 a & 0.011 & 0.00113 & 9700 \\
& D-4 a & 0.017 & 0.14 & 86 \\
\hline
\end{tabular}



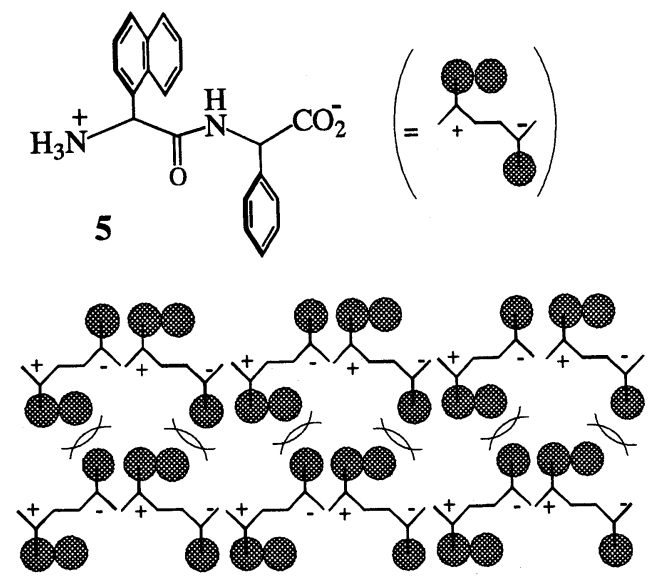

Fig. -7 Steric repulsion between naphthyl groups disturbs the contraction of dipeptide (5) layers.

Table-4 Inclusion of alcohols by dipeptide $(5)^{\mathrm{a}}$.

\begin{tabular}{|c|c|c|}
\hline Guest & $\begin{array}{l}\text { Guest/\% } \\
\text { in complex }\end{array}$ & $\begin{array}{c}\text { Layer } \\
\text { distance/ } \AA\end{array}$ \\
\hline & 75 & 11.9 \\
\hline & 97 & 11.9 \\
\hline & $13^{\mathrm{b}}$ & - \\
\hline & 83 & 13.3 \\
\hline & 95 & 13.3 \\
\hline & n.i. ${ }^{\mathrm{c}}$ & - \\
\hline & $n \cdot i^{c}$ & - \\
\hline & 91 & 14.4 \\
\hline
\end{tabular}

a Crystallization of 5 from methanol and guest (1: $1 \mathrm{vol} / \mathrm{vol}) .{ }^{\mathrm{b}} \mathrm{H}_{2} \mathrm{O}(162)$ and $\mathrm{MeOH}$ (18) were also included. "Not included.

果から, ジペプチドに包接されているゲスト分子の比率 を求め, Table-4 に示した。アルコール分子だけでな く, 常に水分子やメタノール分子も包接されている。ア ルコールのアルキル基がか (嵩)高くなるにつれて層間 が広くなるが, $t-\mathrm{Bu}$ 基では空孔に入りにくくなる。ア ルコール包接体は, 減圧下で $100{ }^{\circ} \mathrm{C} て ゙ ~ 2 \mathrm{~h}$ 加熱する と, 層を支えていたアルコールが除去されてアモルファ スとなることが粉末 X 線回折パターンから示された。

直鎖状アルコールでは, 炭素数が 5 以上になると取り 込まれなくなる。一方，5-ヘキセン-1-オールは包接さ
Table-5 Inclusion of alcohols by dipeptide $(5)^{\mathrm{a}}$.

Guest/\%
in complex $\quad \begin{gathered}\text { Layer } \\ \text { distance/ } \AA\end{gathered}$

a Crystallization of 5 from $\mathrm{MeOH}$ containing a benzyl alcohol. ${ }^{\mathrm{b}} 14 \%$ ee. ${ }^{\mathrm{c}} 41 \%$ ee $(R)$.



Fig. -8 Layer structure of the inclusion complex of dipeptide (5) and allyl alcohol.

れ，二重結合とホスト化合物との間に弱い相互作用があ ることが示唆された。ベンジルアルコールとその $\alpha-ア$ ルキル置換体では, Table-5 に示しように, 層間隔は 広くなるが, アルキルアルコールの場合と異なって， $\alpha$ 位にメチル基が増えるにつれ，その層間隔が狭くなる。 不斉中心を有する 2-メチル-1-フェニル-1-プロパノー ルは, $R$ 体が優先的に包接された。ここでも， $\alpha$ 位にメ チル基の多い方が不斉認識が大きい。これらの事実か ら，アルキル基とジペプチドのベンゼン環との間の $\mathrm{CH}-\pi$ 相互作用がこれらの分子認識に関与している可能 性が強( ${ }^{15)}$ 。

アリルアルコールを包接した 5 の単結晶を与えた。こ の $\mathrm{X}$ 線解析で, 室温では大きな熱振動のため完全な 
Table-6 Inclusion of an ether by dipeptide (5) ${ }^{\mathrm{a}}$.

\begin{tabular}{lcc}
\hline \multicolumn{1}{c}{ Ether } & $\begin{array}{c}\text { Guest/\% } \\
\text { in complex }\end{array}$ & $\begin{array}{c}\text { Layer } \\
\text { distance/ } \AA\end{array}$ \\
\hline $\mathrm{Et}{ }_{2} \mathrm{O}$ & $56^{\mathrm{b}}$ & 12.14 \\
$i-\mathrm{Pr}_{2} \mathrm{O}$ & - & - \\
$\mathrm{THF}$ & 100 & 12.2 \\
$\mathrm{THP}$ & 101 & 12.6 \\
$\mathrm{Dioxane}$ & 88 & 12.3 \\
$\mathrm{MeOCH}{ }_{2} \mathrm{CH}_{2} \mathrm{OMe}$ & 98 & 12.7 \\
$\mathrm{MeO}\left(\mathrm{CH}_{2} \mathrm{CH}_{2} \mathrm{O}\right)_{2} \mathrm{Me}$ & 46 & 12.1 \\
$\mathrm{EtO}\left(\mathrm{CH}_{2} \mathrm{CH}_{2} \mathrm{O}\right)_{2} \mathrm{Et}$ & 42 & 12.2 \\
\hline
\end{tabular}

${ }^{a}$ Crystallization of 5 from $\mathrm{MeOH}-$ an ether

${ }^{\mathrm{b}} \mathrm{MeOH}$ (44) was also included.

データが得られなかったが， $-50^{\circ} \mathrm{C}$ で完全な解析ができ た。結果を Fig.-12 に示した。ジペプチド（5）が層を 形成していること, その層は 1 の層とは異なり, ジペプ チドが完全に直線状ではなくジグザグ構造をとってい る，そしてアリルアルコールがジペプチドのフェニル基 とナフチル基の間の空間に包接されていることが明らか となった。

5 のメタノール溶液に種々のエーテルを加えて放置し ても，包接結晶が析出した ${ }^{16)}$ 。Table-6に示したよう に，鎖状エーテルよりも環状エーテルの方が包接されや すく，また，エーテル錯体を減圧下で加熱しても結晶形 に変化は見られず，ホストーエーテル分子間にかなり強 い相互作用があることが明らかとなった。

エーテル部位が増えた 1,2-ジメトキシエタンでは同 様の $1: 1$ 包接錯体が得られたが, ジエチレングリコール のジメチルあるいはジエチルエーテルではジペプチドと $1: 2$ で結晶化した。この現象の解釈については, 後述 する。

アルコール部位とエーテル部位を併せ持つ 2-エトキ シエタノールも包接結晶（2-エトキシエタノール, メ タノールおよび水をそれぞれ 1 分子ずつ包接）を与え た。粉末 X 線回折から層間隔は $11.0 \AA$ とこれまでにな い小さい值となり，かなり密にパックした結晶であるこ とが示された。単結晶も得られ，X 線構造解析ができ た。ジペプチド分子は, $a$ 軸方向に塩形成により配列 し, ジグザグ構造をとっている。上下のナフチル基同士 またはフェニル基同士が交互に入り込んで，パッキング して層間を縮めている。

このジペプチドの塩形成に 2 -エトキシエタノールの アルコール部位とエーテル部位が関与 $[$ Fig. -12 (c) 参 照], ナフチル基とフェニル基との近づきで, ジペプチ ド配列形が決定されたと見なせる ${ }^{16)}$ 。そして芳香環で 囲まれた空間にエトキシエタノールが, ベンゼン環で囲 まれた空間にメタノールと水がそれぞれ 1 分子ずつ包接 (a)
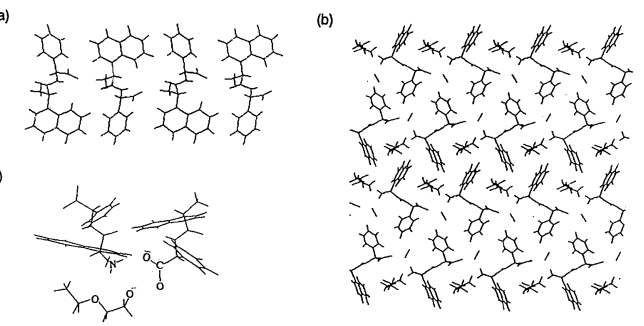

(a) View from $\mathrm{c}$-axis without guest molecules for clarify. (b) View from a-axis. (c) Partial structure for salt formation.

Fig.-9 X-ray crystal structure of the inclusion complex of dipeptide (5) and $\mathrm{EtOCH}_{2} \mathrm{CH}_{2}$ $\mathrm{OH}$.

Table-7 Inclusion of a sulfoxide by $5^{\mathrm{a}}$.

\begin{tabular}{|c|c|c|c|}
\hline \multirow{2}{*}{ Sulfoxide } & \multicolumn{2}{|c|}{ Sulfoxide in complex } & \multirow{2}{*}{$\begin{array}{c}\text { Layer } \\
\text { distance/ } \AA\end{array}$} \\
\hline & Yield/\% & $e e / \%$ & \\
\hline $\mathrm{OCH}_{3}$ & 95 & $88(\mathrm{~S})$ & 13.7 \\
\hline$-\mathrm{SOCH}_{2} \mathrm{CH}_{3}$ & 57 & $14(\mathrm{~S})$ & n.d. ${ }^{b}$ \\
\hline $\mathrm{OCH}\left(\mathrm{CH}_{3}\right)_{2}$ & 58 & $18(\mathrm{~S})$ & n.d. ${ }^{b}$ \\
\hline $\mathrm{SOCH}_{3}$ & 78 & $90(\mathrm{~S})$ & 14.5 \\
\hline $\mathrm{SOCH}_{3}$ & 90 & $86(S)$ & 14.1 \\
\hline $\mathrm{OCH}_{3}$ & 93 & $89(\mathrm{~S})$ & n.d. \\
\hline $\mathrm{CH}_{2} \mathrm{SOCH}_{3}$ & 70 & $4(\mathrm{~S})$ & 12.9 \\
\hline $\mathrm{CH}_{2} \mathrm{SOCH}_{3}$ & 65 & $87(\mathrm{~S})$ & 13.4 \\
\hline
\end{tabular}

${ }^{a}$ Cystallization of 5 from water containing a sul-

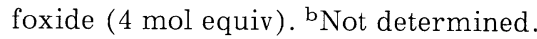

されている。

ジペプチド（5) を水に溶かし，アルキルフェニルスル ホキシド（ラセミ体）を加えると，スルホキシドを包接 した結晶が析出する。結果を Table-7 にまとめたが, アルキル基が大きくなると, 包接率と不斉認識率 $(e e)$ が低下する。メチルフェニルスルホキシドでは, $S$ 体が 高い立体選択性で包接された。この様な現象は，ジペプ チド (5) により形成される固相の包接空間が 1 に比べて 小さくなったことで説明される。

メタノールを包接した 5 固体を四塩化炭素に懸濁さ せ，メチルフェニルスルホキシドのラセミ体とかくはん した $\left(40^{\circ} \mathrm{C} / 7 \mathrm{~d}\right)$ ところ， $(S)$-メチルフェニルスルホキ シドがメタノール分子と置換 $(57 \% e e)$ した。このよ うに, ジペプチド (5) のゲスト包接空間は, ゲスト交換 
が可能である。メタノール包接の 5 固体を $\mathrm{THF}$ 中でか くはんすると，メタノールが THF に完全に交換する。 また, X 線回折で構造が明らかになっている2-エトキ シエタールを包接した 5 の結晶も THF とのゲス卜交換 を受ける。層間隔は, $10.9 \AA$ から $12.3 \AA$ に拡大する。 この様に, 5 の結晶配列は, ゲスト分子により柔軟に構 造を変化させる。

\section{5 ジペプチド固相によるジスルホキシド体 の包接}

ジペプチドの配列によって生まれる取り込み空間は, 先に示した Fig.-1 から明らかなように，層間にはゲス 卜分子 2 つ分の空間が存在することになっている。1の 取り込み空間にメチルフェニルスルホキシドが包接され た場合, 上下 2 個のスルホキシド分子を連結させても, 本空間に包接できると考えられる。そこで， 3 種のジス ルホキシド (6〜8) を合成し, 層間への取り込みを検討 した。
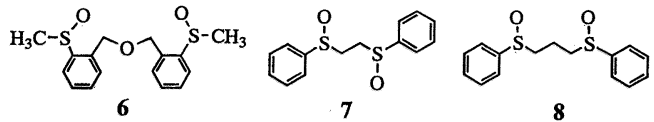

まず，ジペプチド（1）を水に懸濁させて取り込みを 行ったところ, $(R, R)-6$ を高収率かつ高立体選択的に 取り込んだ。しかし，7 8 では取り込み錯体は得られ なかった ${ }^{17)}$ なこれは, ジペプチドの層構造 (Fig.-1)

Table-8 Inclusion of disulfoxides $(6 \sim 8)$ by dipeptide (1 and 5)

\begin{tabular}{ccrcr}
\hline \multirow{2}{*}{ Disulfoxide } & \multicolumn{2}{c}{ in 1 } & \multicolumn{2}{c}{ in 2 } \\
\cline { 2 - 5 } & Yield/\% & ee/\% & Yield $/ \%$ & ee/\% \\
\hline 6 & 73 & $91(R, R)$ & 19 & $2(S, S)$ \\
7 & 32 & $<1(S, S)$ & 42 & $88(S, S)$ \\
8 & 37 & $6(S, S)$ & 48 & $85(S, S)$ \\
\hline
\end{tabular}

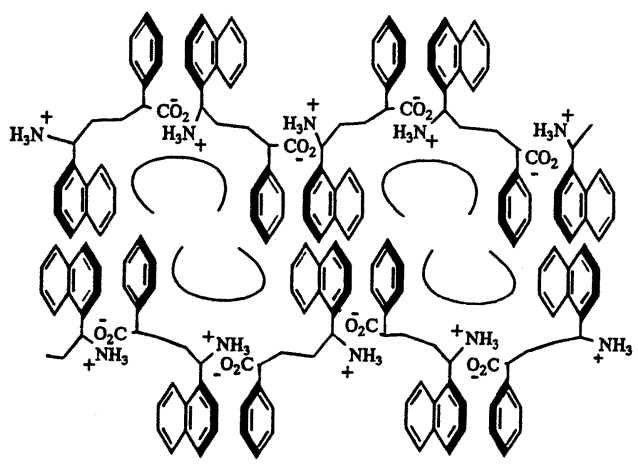

Fig.-10 Imaginary arrangement of the layers of dipeptide (5)
からの予想と完全に一致する。一方，ジペプチド (5)を クロロホルムに懸濁させたところ， $(S, S)-7$ と $(S, S)-$ 8 を高立体選択的に取り込んだが， 6 はほとんど包接さ れなかった。

このように, 1 と 5 が包接できるジスルホキシドの構 造を異にする。これは, Fig.-10に示すように層の重 なり方がジペプチド (5) では異なり, 包接空間の形が異 なるためと解釈できる。

\section{6 おわりに}

以上述べてきたように，ジペプチド結晶場は末端アミ ノ基と他分子の末端カルボキシル基との塩形成をもと に，分子集合体を形成する。この分子集合体は層構造を なし，その層間に種々の分子（ゲスト）を取り込んで包 接する。包接ゲスト分子の形状に特異性がみられ，また その形状にしたがって層構造を変化させる。まさに，柔 軟な分子認識場モデルとなる。今後，これらの分子認識 場から反応場への展開が期待される。

本研究は, 研究室のスタッフ（藤田 誠講師, 赤染元 浩助手) ならびに引用文献に記載の多くの学生諸君の努 力の成果である。また, 東工大の岡畑恵雄先生（安永浩 一君）との共同研究の結果についても引用させていただ いた。稿を閉じるにあたり，以上の方々に感謝の意を表 したい。

\section{〔平成 6 年 (1994 年) 5 月 6 日受理〕}

\section{文献}

1) C.A. Hunter, J.K.M. Sanders, J. Am. Chem. Soc., 112, 5525 (1990) およびその引用文献

2) W.L. Jorgensen, D.L. Severance, J. Am. Chem. Soc., 112, 4768 (1990) およびその引用文献

3) M. Nishio, M. Hirota, Tetrahedron, 45, 7201 (1989) ; 廣田 榱, 西尾元宏, 化学, 46, 592 (1991)

4) 日本化学会編, “化学総説 No. 40, 分子集合体一その組 織化と機能”, 学術出版センター (1983)

5）竹本喜一, “包接化合物の化学” 東京化学同人 (1969); K. Takemoto, "Inclusion Compounds", Academic Press, London (1984). vol. 2, p. 47

6) E. Giglio, "Inclusion Compounds", Academic Press, London (1984). vol. 2, p. 207

7) M. Fujita, J. Yazaki, K. Ogura, J. Am. Chem. Soc., 112, 5645 (1990); M. Fujita, J. Yazaki, K. Ogura, Tetrahedron Lett., 32, 5586 (1991); M. Fujita, J. Yazaki, K. Ogura, Chem. Lett., 1991, 1031; M. Fujita, S. Nagao, S. Iida, K. Ogata, K. Ogura, J. Am. Chem. Soc., 115, 1574 (1993); M. Fujita, Y.J. Kwon, S. Washizu, K. Ogura, J. Am. Chem. Soc., 116, 1151 (1994); M. Fujita, F. Ibukuro, H. Hagihara, K. Ogura, Nature, 367, 720 (1994)

8) K. Ogura, T. Uchida, M. Noguchi, M. Minoguchi, A. Murata, M. Fujita, Tetrahedron Lett., 31, 3331 (1990)

9) A.M. Barrett, V.A. Cullum, Brit. J. Pharmacol., 
34, 43 (1968)

10) T. Matsuo, T. Nishioka, M. Hirano, Y. Suzuki, K. Tsushima, N. Itaya, N. Yoshioka, Pesti. Sci., 11, 202 (1980)

11）小倉克之, 野口 誠, 藤田 誠, 日本化学会第 58 春季 年会, 講演予稿集 II , p. 1458 (1989)

12）岡畑恵雄, 安永浩一, 小倉克之, 日本化学会第 61 春季 年会, 講演予稿集 II, p. 2013 (1991)

13) Y. Okahata, K. Yasunaga, K. Ogura, J. Chem.
Soc., Chem. Commun., 1994, 469

14）小倉克之, 澄川敦子, 田中 修, 藤田 誠, 日本化学会 第 63 春季年会, 講演予稿集 II, p. 1264 (1992)

15）小倉克之, 園部龍一, 澄川敦子, 藤田 誠, 日本化学会 第 67 春季年会, 講演予稿集 II, p. 1170 (1994)

16）小倉克之，澄川敦子，藤田 誠，日本化学会第 67 春季 年会, 講演予稿集 II , p. 1166 (1994)

17）小倉克之, 澄川敦子, 藤田 誠, 日本化学会第 65 春季 年会, 講演予稿集 II , p. 231 (1993) 